\title{
Effect of Resources on Competitive Strategies Through Unique Capability in Chicken Distributor Companies in Dki Jakarta Province
}

\author{
$1^{\text {st }}$ Siti Mariam ${ }^{1}, 2^{\text {nd }}$ Abdul Haeba Ramli ${ }^{2}$ \\ \{marry.dbm@gmail.com ${ }^{1}$, abdul.haeba@trisakti.ac.id ${ }^{2}$ \} \\ Institut Ilmu Sosial dan Manajemen STIAMI ${ }^{1}$, Universitas Trisakti ${ }^{2}$
}

\begin{abstract}
The competitive strategy in the chicken distribution company in Jakarta indicates low resources and unique capability. The purpose of this study is to determine the effect of low resources and unique capability to competitive strategy. Quantitative methods are used in this study. Population is the employees of the chicken distribution company in Jakarta with more than 2.000 people. Sampling technique used is purposive sampling with the number of samples of 104 people. Data collection technique uses questionnaires and regression analysis. Finding on the research results shows that there are positive and significant influence of resources on unique capability and positive and significant influence of resources on competitive strategy, positive but not significant influence of unique capability on competitive strategy and also the influence of company resources on unique capability to competitive strategy.
\end{abstract}

Keywords: Competitive Strategy, Unique Capability, Resources And Chicken Distribution Company.

\section{Introduction}

Consumption of animal foods is increasing steadily due to an increase in population and income levels, chicken prices are relatively cheaper than other meats and increasing the development of other sectors that support chicken farming, for example opening new restaurants, restaurants and supermarkets increasing, increasing public awareness of nutrition fulfillment, community needs at certain times such as marriage parties, and high selling prices in the fasting month, Eid al-Fitr, Christmas, and others (PDSIP, Ministry of Agriculture, 2016). The need to fulfill animal food needs has supported business development in the field of chicken production.

One sector that plays a major role in the meat business is the chicken distributor sector. Distributor of company chicken / business that connects suppliers (suppliers) with consumers, cooperation to make both parties synergetic and can guarantee the accuracy in the distribution of chicken products. In the end it will increase the amount of production, compared to the number of requests. With the increase in the number of production, it will definitely increase competition in seizing the market for these products. Questioning every chicken distributor company will do a competitive strategy to improve and improve the performance of the company. 
In DKI Jakarta Province there are currently 1,153 chicken slaughterhouses (TPA), each of which has a cutting capacity of 402,000 head / day and 216 locations for chicken shelters (TPnA) or also called chicken distributor companies and employees as a whole are more than 2,000 people spread in 5 (five) municipalities: Central Jakarta, East Jakarta, South Jakarta, West Jakarta, and North Jakarta, with a chicken holding capacity of 452,460 birds per day (DKI Jakarta Province Marine and Agriculture Food Security Service, 2018).

Wheelen et al. (2015) states that competitive strategies focus on increasing the competitive position of a product or service from a business unit or company in an industry or a particular market segment where they compete. But the implementation of competitive strategy that is still not optimal by chicken distributors has an impact on the performance of chicken distributors. This is consistent with the results of the research of Hahn and Powers (2010). Several studies of the determinants of corporate competitive advantage have been carried out, for example Tracey et al (1998), and Salazar et al (2012). In this case, Toha (2001) underlines the role of leaders in directing the human resources they manage to move optimally toward the target without violating existing boundaries.

However, the existing studies have not specifically reviewed the business units in the livestock industry, especially the chicken distributor business unit with a relatively distinctive character of capital and market sources. Therefore, this research will fill the literature gap. Specifically, this study will examine the effect of resources on competitive strategies through unique capabilities in chicken distributor companies in DKI Jakarta Province.

\section{Literature Review}

\subsection{Resources}

In the opinion of Pearce and Robinson (2015), based on RBV, each company is fundamentally different because each has a unique collection of resources consisting of tangible assets, intangible assets, and organizational capabilities to utilize these assets. Based on the Resource-Based Model, Hitt, Ireland, \& Hoskisson (2015) assume that each organization is a collection of unique resources and capabilities. The uniqueness of resources and capabilities is the basis of the company's strategy and its ability to obtain above-average returns. Resources are input to the company's production processes, such as capital equipment, individual employee expertise, patents, finance, and talented managers. Hsieh, Chen, Ming (2011) conducted a literature review regarding the relationship between resources and competitive strategies. Competitive strategies are designed based on individual specifications, consistent with human resource strategies, namely skills-oriented and innovation strategies.

\subsection{Unique Capability}

Unique capability is defined by Makadok (2001) as a specific resource that is owned by the company and invested in increasing the productivity of other resources within the company. Simonceska (2008) underlines that unique capabilities are the strengths and characteristics of the company and its exploitation efforts to encourage companies to create certain products that excel in competition in the market. Meanwhile, according to Wheelen et al (2015), unique capabilities related to core capabilities are the company's superior expertise that can provide the greatest benefits to customers. 


\subsection{Competitive Strategy}

Hubbard and Beamish (2011) state business strategies related to how organizations position their business more competitively than other similar industries. Another notion of competitive strategies is stated by Thompson et al. (2014) where the competitive strategy of a company relates to game planning from management to compete successfully, namely specific businesses to serve customers, strengthen market position, face maneuvers from competitors, respond to market conditions, and to achieve certain types of excellence.

In relation to the company's efforts to be competitive in its market, there are several strategies that can be carried out as stated by Hitt, Ireland, Hoskisson (2015) that companies can choose five business strategies to build and maintain the company's strategic position against competitors, which consists of: cost of leadership, differentiation, focused cost leadership, focused differentiation, and integrated cost leadership / differentiation.

Based on the theory and the results of the above assessment, the conceptual framework like the picture 1 below:

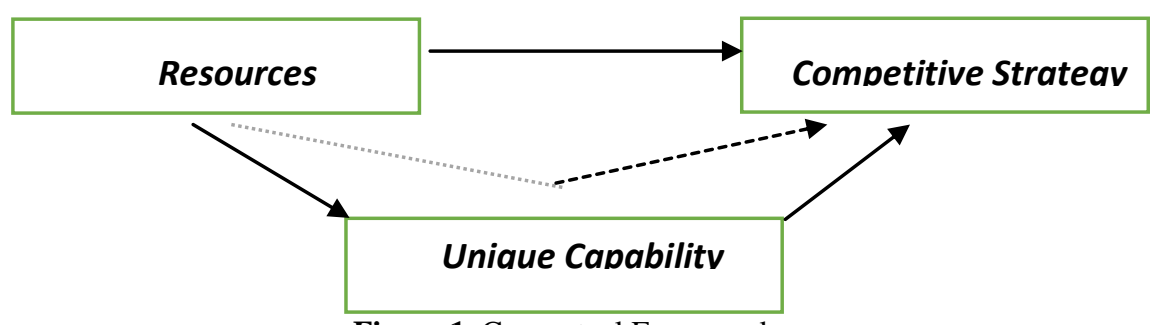

Figure 1. Conceptual Framework

\section{Hypothesis Development}

According to Hitt, Ireland \& Hoskisson (2013) based on the RBV mode it is assumed that each organization is a unique collection of resources and capabilities. So that both have a mutually influential relationship to produce optimization of company performance. Likewise according to Wheelen et al (2015), that the uniqueness of resources and unique capabilities is a superior expertise of companies that can provide the greatest benefits to their customers.

Based on various results of the above research, the hypotheses developed in this study are:

H1: Resources have a positive and significant effect on unique capabilities.

The company's internal resources are an important key in creating competitive advantage (Omerzel \& Gulev, 2011). Likewise according to Wheelen et al (2015), that the uniqueness of resources is a superior expertise of a company that can provide the greatest benefits to its customers.

Based on various results of the above research, the hypotheses developed in this study are:

$\mathrm{H} 2$ : Resources have a positive and significant effect on competitive strategies.

Simonceska (2008) underlines that unique capabilities are the strengths and characteristics of the company and its exploitation efforts to encourage companies to create certain products that excel in competition in the market. Likewise with Wheelen et al (2015), that unique 
capacity is a superior capacity of a company that can provide the greatest benefits to its customers. Research conducted by Rentala, Anand and Shaban (2014) in the Indian pharmaceutical industry also supports the conclusions above. Unique capability plays a role in the process of determining competitive strategies.

Based on various results of the above research, the hypotheses developed in this study are:

H3: Resources have a positive and significant effect on bersing strategies.

The findings of Hsieh, Chen, Ming (2011) related to the relationship between resources, unique capabilities and competitive strategies. Competitive strategies are designed based on individual specifications, consistent with human resource strategies, namely skill-oriented strategies and innovations that are the company's unique capabilities. One study of the determinants of competitive strategies was carried out by Boasson (2001), who conducted studies on the pharmaceutical industry in the US. In this study, Boasson (2001) places the characteristics and location of the company as a resource element that influences unique capabilities. The research concludes the important role of unique capabilities for the development of the company's competitive strategy.

Based on various results of the above research, the hypotheses developed in this study are:

H4: Resources have a negative and significant effect on the competitive strategy through an organization comitment.

\section{Research Methods}

The method used in this study is exploratory research with the data sources used in this study are primary data covering all respondents who came from chicken distributors in DKI Jakarta Province. The sample is chicken distributor executives from 38 chicken distributor companies in the entire DKI Jakarta Province with a total number of 104 people from more than 2,000 population populations.

The analysis method starts from looking at the characteristics of the data through descriptive statistics and then the analysis of the multivariate data analysis model includes factor analysis and Partial Least Square (PLS). Because of the limited number of samples used under 200 and the PLS model also does not require data that is not normally distributed (Cassel, 1999), besides that this PLS model is a model that is able to explain complex structural models.

The measurement instruments for the three variables in this study are for resource variables using instruments adopted from Pearce and Robinson (2015). Furthermore, the instruments of the unique capability variable from Wheelen et al (2015) and competing strategy variables were adopted from Hitt, Ireland, Hoskisson (2015). To test the validity of the instrument used the product moment correlation formula proposed by Pearson (Arikunto, 2008: 72). Test the validity of the Resource variable, unique capabilities and competitive strategies carried out by validity test as in the table below: 
Table 1. Outer Loadings

\begin{tabular}{|c||c||c|c|}
\hline & Resources & Unique Capability & Competitive strategy \\
\hline 1 & 0.969290 & 0.902966 & 0.959083 \\
\hline \hline 2 & 0.960743 & 0.905756 & 0.978724 \\
\hline 3 & 0.910050 & 0.925698 & 0.983672 \\
\hline \hline 4 & 0.861810 & & 0.978855 \\
\hline \hline 5 & 0.975592 & & \\
\hline
\end{tabular}

In the table above, shows the value of t-value in each indicator of the study has good validity. This is based on good validity criteria, where the value of the t-value of each item above is greater than the benchmark value $t$ of 0.3 ( $\mathrm{t}$-value> of 0.3 ), Masrun in Sugiyono, (2009). So, all items are declared valid.

Tabel 2. Reliability Test Results

\begin{tabular}{lccl}
\hline Variables & N of Items & Cronbach's Alpha & Keputusan \\
\hline Resources & 5 & 0.964 & Reliabel \\
Unique Capability & 3 & 0.943 & Reliabel \\
Competitive Strategy & 4 & 0.916 & Reliabel \\
\hline
\end{tabular}

Source: 2018 Data Results.

Reliability testing is related to the consistency, accuracy, and predictability of a measuring instrument. According to Sekaran (2006), the basis for decision making for reliability testing is as follows:

a. If the Cronbach's Alpha coefficient is> 0.6, then Cronbach's Alpha is acceptable (reliable construct)

b. If Cronbach's Alpha <0.6 then Cronbach's Alpha is poor acceptable (unreliable construct).

From the table above, all variables with Cronbach's Alpha are greater than 0.60 , so the variables are considered reliable and this research can be continued.

\section{Results And Discussion}

Testing of the four hypotheses proposed was carried out using Structural Equation Modeling (SEM) with the help of PLS software. Hypothesis test decision making is to look at the results of t-value, where if the value is positive it means that the variable has a positive effect, while to see its significance is to refer to the t-statistic value between variables, if the $t$ value obtained is greater than t-table amounting to 1.96 , meaning that the effect is significant. The results of this study, can be seen below: 
Table 3. Hypothesis Test Result

\begin{tabular}{|c|c|}
\hline Variables & T Statistics (|O/STERR|) \\
\hline \hline Resources -> Unique Capability & 4.541880 \\
\hline \hline Resources -> Competitive Strategy & 3.232623 \\
\hline \hline Unique Capability -> Competitive Strategy & 1.130606 \\
\hline Resources $->$ Unique Capability -> Competitive St & 2.123876 \\
\hline
\end{tabular}

Source: 2018 Data Results of PLS

In the table above shows that all influences between one variable to another variable show positive values, including:

1. The Effect of Resources on Unique Capability is positive and significant because the value of t-value is 4.541880 which means positive and significant because it is greater than the $\mathrm{t}$ table of 1.96.

2. Effect of Resources on competitive strategies is positive and significant because the value of t-value is 3.232623 which means positive and significant because it is greater than ttable of 1.96 .

3. The effect of unique capability on competitive strategies is positive but not significant because the t-value is 1.130606 which is positive but not significant because it is smaller than t-table of 1.96.

4. The Effect of Resources on Competitive Strategies through Unique Capability is positive and significant because the t-value is 2.123876 which means positive and significant because it is greater than t-table of 1.96 .

\section{Conclusion}

The conclusion of this study was formulated based on the results of hypothesis testing. The conclusion of this study is that the positive effect of resources on unique capabilities is proven, then the positive effect of resources on competing strategies is also proven, then the positive effects of unique capabilities on competitive strategies are proven but not signifivant. As well as proven the positive influence of resources on competitive strategies through unique capabilities.

\section{Managerial Implications}

The results of the conclusions above, will provide a reference to company leaders because the results of this study indicate that competitive strategies will be increased positively and significantly if the company's unique Resource and Capability level is taken into account. So that the company will be able to achieve the desired goals.

\section{Limitations Of Research And Suggestions}

This research was only conducted on employees of a chicken distributor business company in Jakarta, so the results cannot be generalized to all business industries. And this 
study only examines resources, competitive strategies, and unique capabilities, so it is necessary to try the development of other variables as determinants of forming competitive strategies, such as technology adoption and management of innovation (Tsai, Tsai, Li, \& Lin, 2012).

\section{References}

[1]. Ansoff, H.I. 1972, The Concept of Strategic Management. Journal of Business Policy, 2 (4), 2 - 7.

[2]. Auh, S., \& Shih, E. (2009). Brand name and consumer inference making in multigenerational product introduction context. Journal of Brand Management, 16(7), 439-454.

[3]. Barth, Brumbaugh, \& Wilcox (2000). The Repeal of Glass-Steagall and the Advent of Broad Financial Banking. Journal of Economic Perspectives, 2000.

[4]. Biro Pusat Statistik, 2014. Direktori Distributor unggas besar dan sedang di Prov DKI Jakarta.

[5]. Boasson, V., \& MacPherson, A. (2001). The role of geographic location in the financial and innovation performance of publicly traded pharmaceutical companies: empirical evidence from the Untied States. Environment and Planning A, 33(8), 1431-1444.

[6]. Boyd, Chang, dan Smith (1998). Moral Hazard Under Commercial and Universal Financial Journal of Money, Credit and Financial, Vol. 30, No. 3, Part 2, August 1998

[7]. Camdessus (1997). The Asian Financial Crisis and the Opportunities of Globalization, Second Committee of the United Nations General Assembly New York Volume 11, Issue 5, pages 433450, Nov.

[8]. Cassel, C., Hackl, P., Westlund, A.H., 1999. Robustness of Partial Least Squares Method for estimating Latent Variable Quality Structures. Journal of Applied Statistics 26 (4), 435-446.

[9]. Chaffe (1985). Three models of strategy. Academy of Management Review, 1985. Vol 10. No.1.

[10]. Chandler, Alfred D., Jr., (1962). Strategy and structure (MIT Press, Cambridge, MA).

[11]. Chin W., 2000, Partial Least Squares for Researchers: An Overview and Presentation of Recent Advances Using the PLS Approach, http://disc- nt.cba.edu/chin/indx.html

[12]. Clark, G., Palaskas, T., Tracey, P., \& Tsampra, M. (2004). Globalization and competitive strategy in Europe's vulnerable regions: firm, industry and country effects in labour-intensive industries. Regional Studies, 38(9), 1085-1100.

[13]. Cohen, J., 1992. A Power Primer. Psychological Bulletin 112 (1), 155-159.

[14]. Daryanto, A. 2008, Poultry Industries Outlook. Makalah disampaikan dalam Seminar Nasional yang bertajuk "Strategi Usaha Perunggasan dalam Menghadapi Krisis Global" yang diselengarakan oleh Masyarakat Ilmu Perunggasan Indonesia (MIPI), 26 Oktober 2009, Ruang Matohi MB-IPB.

[15]. David, Fred R, 2013, Strategic Management, Concepts \& cases. Pearson Education Limited, England.

[16]. Dinas Ketahanan Pangan Kelautan dan Pertanian Provinsi DKI Jakarta, 2018. Laporan Tahunan, Dinas Ketahanan dan Pertanian Provinsi DKI Jakarta.

[17]. Direktorat Jenderal Peternakan dan Kesehatan Hewan Kementerian Pertanian, 2017. Statistik Peternakan dan Kesehatan Hewan. Livestock and Animal Health Statistick.

[18]. Floyd, S. W., \& Wooldridge, B. (1990). Path analysis of the relationship between competitive strategy, information technology, and financial performance. Journal of management information systems, 7(1), 47-64.

[19]. Hafeez, K., Zhang, Y., \& Malak, N. (2002). Determining key capabilities of a firm using analytic hierarchy process.International journal of production economics, 76 (1), 39-51.,

[20]. Hahn, William \& Powers, Thomas L, 2010, Strategic Plan Quality, Implementation Capability, and Firm Performance, Academy of Strategic Management Journal 9.1 : 63 - 81 .

[21]. Hair JF, Sarstedt M, Pieper TM, Ringle CM (2012). The Use of Partial Least Squares Structural Equation Modeling in Strategic Management Research: A Review of Past Practices and Recommendations for Future Applications. Long Range Planning, (45), 3.

[22]. Hair, J.F., Ringle, C.M., Sarstedt, M., (2013). A Primer on Partial Least Squares Structural Equation Modeling. Sage, Thousand Oaks. 
[23]. Hair, Sarstedt, Pieper Torsten M.and Ringle Christian M., (2012), The Use of Partial Least Squares Structural Equation Modeling in Strategic management Research: A Review of Past Practices and Recommendation for Future Applications, Long Range Planning (45), 320-340.

[24]. Hamel, G dan Prahalad, C.K (1989). The Resource-Based Theory of Competitive Advantage: Implication for Strategy Formulation. California Management Review. 1989.

[25]. Hamel, G. (1991). Competition for competence and interpartner learning within international strategic alliances.Strategic management journal, 12(S1), 83-103.

[26]. Henseler J, Ringle CM, Sarstedt M. (2016).Testing Measurement Invariance of Composites Using Partial Least Squares. International Marketing Review, (33), Issue 3.

[27]. Hill, M. J. (1997). The policy process in the modern state. Prentice Hall PTR.

[28]. Hitt, Michael A. ; Ireland, R. Duane; Hoskisson, Robert E., 2015. Strategic Management : Competitiveness \& Globalication: Concepts and Cases, Eleventh Edition, Stampford: Cengage Learning.

[29]. Hubbard G., Beamish, Paul, 2011, Strategic Management-Thinking, Analysis, Action, Pearson Australia, 4 th Edition.

[30]. Hsieh, Y. H., \& Chen, H. M., 2011, Strategic Fit among Business Competitive Strategy, Human Resource Strategy, and Reward System. Academy of Strategic Management Journal, 10 (2), 11 32.

[31]. John, \& Saunders (1994). Product Replacement: Strategies for Simultaneous Product Deletion and Launch, Journal of Product Innovation Management.

[32]. Kaliappen, Narentheren \& haim Hilman, 2004, Does Service Innovation Act as a Mediator in Differentiation Strategy and Organizational Performance Nexus? An Empirical Study, Asian Social Science; Vol.10, No.11.

[33]. Krapez, Jana; Ales Groznik, Miha Skerlavaj, 2012, Contextual Variables of Open Innovation Paradigm In The Business Environment of Slovenian.

[34]. Kotler, Philip \& Kevin Lane Keller. 2012. Marketing Management, 14e, Global Edition, Pearson Educational Limited, England.

[35]. Learned, A., Christensen, E.P., Andrews, C.R. and Guth, W.R. (1965). Business Policy: Text and Cases. Homewood, IL: Irwin

[36]. Makadok, R. (2001). Toward a synthesis of the resource-based and dynamic-capability views of rent creation.Strategic management journal, 22(5), 387-401.

[37]. McDougall, P. P., Robinson Jr, R. B., Covin, J., \& Herron, L. (1990). The effects of industry growth and strategic breadth on the content of new venture strategies (pp. 117-131). Wellesley: Babson College.

[38]. Malhotra. Naresh K., 2010, Marketing Reseach : An Applied Orientation Sixth. Edition Pearson Education.

[39]. Masri Singarimbun dan Effendi, 2011, Metoda Penelitian Survei, LP3ES.Pusat Data dan Sistem Informasi Pertanian (PDSIP), Sekretariat Jenderal Kementerian Pertanian, 2016. Outlook Daging Ayam : Komoditas Pertanian Subsektor Pternakan.

[40]. Pearce, john A. II, Richard B. Robinson, Jr., 2015, Strategic Management: Planning for Domestic \& Global Competition, International Edition, New York : McGraw Hill.

[41]. Pertusa-Ortega, E. M., Molina-Azorín, J. F., \& Claver-Cortés, E. (2010). Competitive strategy, structure and firm performance: A comparison of the resource-based view and the contingency approach. Management Decision, 48(8), 1282-1303.

[42]. Pires, Guilherme D. \& Janet Aisbett., 2003, The relationship between technology adoption and strategy in business-to-business markets: The case of E-commerce', Industrial Marketing Management, vol. 2033

[43]. Pfaltzgraff \& Dougherty, 1990, 1- - 11, Library.binus.ac.id.

[44]. Pusat Data dan Sistem Informasi Pertanian (PDSIP), Sekretariat Jenderal Kementerian Pertanian, 2016. Outlook Daging Ayam : Komoditas Pertanian Subsektor Peternakan.

[45]. Rose, P dan Hudgins, S (2006). Management and Financial Services. 
[46]. Salazar, López, A., Contreras Soto, R., \& Espinosa Mosqueda, R. (2012). The impact of financial decisions and strategy on small business competitiveness. Global Journal of business research, 6(2), 93-103.

[47]. Sanchez, R., \& Heene, A. (Eds.). (1997). Strategic learning and knowledge management (pp. 16387). Chichester: Wiley

[48]. Sanchez, R., \& Heene, A. (1997). Reinventing strategic management: New theory and practice for competence-based competition. European Management Journal, 15(3), 303-317.

[49]. Saunders, M., P. Lewis \& A. Thornhill, 2006, Research Methods for Business Students. Third Edition. USA: Prentice-Hall, Financial Times Press.

[50]. Simonceska, L. (2012). The changes and innovation as a factor of competitiveness of the tourist offer (The Case of Ohrid). Procedia-Social and Behavioral Sciences, 44, 32-43.

[51]. Sugiyono, 2009, Metode Penelitian Bisnis (Pendekatan Kuantitatif, kualitatif dan R\&D). Bandung Alfabeta.

[52]. Tan, Justin. "J., and Robert J." (1994): 1-20.

[53]. Tracey, M. (1998). The decline and fall of public service broadcasting. Oxford University Press.

[54]. Thompson, Arthur A; Peteraf, Margareth A.; Gamble, John e.; Strickland III, A,J., 2014, Crafting and Executing Strategy, The Quest for Competitive Advantages, Concepts and Cases, Nineteenth Edition, McGraw Hill Education.

[55]. Wheelen, Thomas L., Hunger, J. David; Hoffman, Alan N., \& Bamford, Charles E. 2012, Concepts in Strategic Management and Business Policy. Pearson.

[56]. Wheelen, Thomas L., Hunger, J. David; Hoffman, Alan N., \& Bamford, Charles D. 2015, Strategic Management and Business Policy: Globalization, Innovation, and Sustaibility, 14 th, Global Edition, Pearson.

[57]. Wang, Yijing; Berens, Guido; Van Riel, Cees B M, 2012, Competing In The Capital Market With A Good Reputation, Corporate Reputation Review $15.3: 198$ - 221. 